\title{
Profile of nursing diagnoses of hospitalized patients in an infectious disease unit
}

\author{
Perfil diagnóstico de enfermagem de pacientes hospitalizados em unidade de infectologia
}

Perfil diagnóstico de enfermería de los pacientes hospitalizados en la unidad de enfermedades infecciosas

\author{
Vinicius Lino de Souza Neto ${ }^{a}$ \\ Lidiane Lima de Andrade ${ }^{b}$ \\ Glenda Agrab \\ Marta Miriam Lopes Costac \\ Richardson Augusto Rosendo da Silva ${ }^{d}$
}

DOI: $\quad$ http://dx.doi.org/10.1590/1983-

1447.2015.03.51495

\footnotetext{
aniversidade Federal do Rio Grande do Norte (UFRN). Programa de Pós-Graduação em Enfermagem. Natal, Rio Grande do Norte, Brasil.

b Universidade Federal da Paraíba (UFPB). Programa de Pós-Graduação em Enfermagem. João Pessoa, Paraíba, Brasil.

c Universidade Federal da Paraíba (UFPB). Programa de Pós-Graduação em Enfermagem. Departamento de Enfermagem de Saúde Pública e Psiquiatria. João Pessoa, Paraíba, Brasil.

d Universidade Federal do Rio Grande do Norte (UFRN). Centro de Ciências da Saúde. Programa de Pós-Graduação em Enfermagem. Departamento de Enfermagem. Rio Grande do Norte, Natal, Brasil.
}

\section{ABSTRACT}

Objective: To define the profile of nursing diagnoses of hospitalized patients at an infectious diseases unit.

Methods: This is a descriptive study based on the quantitative approach conducted at an infectious diseases unit in Paraiba, Brazil, from January to February 2014. The data collection instrument was based on the Theory of Basic Human Needs by Wanda de Aguiar Horta, followed by the classification system CIPE ${ }^{\oplus}$ version 2.0 to construct the diagnoses.

Results: Data analysis resulted in 36 nursing diagnoses statements, with a higher prevalence of impaired food intake, cachexia, impaired spontaneous bladder elimination, impaired oral cavity hygiene, exposure to contamination, rapid heart rate, insomnia, drug abuse, alcohol and tobacco abuse, social isolation, acceptance and fear.

Conclusions: The identification of a diagnostics profile is critical to guide nursing interventions.

Keywords: Nursing process. Nursing care. Communicable diseases.

\section{RESUMO}

Objetivo: delinear o perfil diagnóstico de enfermagem de pacientes hospitalizados em unidade de infectologia.

Métodos: trata-se de um estudo descritivo, com abordagem quantitativa, realizado em unidade de infectologia da Paraíba, Brasil, no período de janeiro a fevereiro de 2014. Para a coleta de dados, utilizou-se um instrumento construído a partir da teoria das necessidades humanas básicas de Wanda de Aguiar Horta; posteriormente, foi utilizada a CIPE versão 2.0 como sistema de classificação para a construção dos diagnósticos.

Resultados: após a análise dos dados, elencaram-se 36 afirmativas de diagnósticos de enfermagem, apresentando-se com maior prevalência estas: ingestão de alimento prejudicada, caquexia, eliminação vesical espontânea comprometida, higiene da cavidade oral prejudicada, exposição à contaminação, ritmo cardíaco acentuado, insônia, abuso de drogas, abuso de álcool e tabaco, isolamento social, aceitação e medo.

Conclusões: por fim, nota-se que a identificação do perfil diagnóstico é essencial para o direcionamento das intervenções de enfermagem.

Palavras-chave: Processos de enfermagem. Cuidados de enfermagem. Doenças transmissíveis.

\section{RESUMEN}

Objetivo: Definir el perfil de los diagnósticos de enfermería de los pacientes hospitalizados en la unidad de enfermedades infecciosas. Métodos: Se trata de un estudio descriptivo, con abordaje cuantitativo, realizado en la unidad de enfermedades infecciosas de Paraiba, Brasil, de enero a febrero de 2014. Para la recolección de datos se utilizó un instrumento construido a partir de la teoría de las necesidades humanas básicas de Wanda de Aguiar Horta, más adelante se usó la CIPE® versión 2.0 como sistema de clasificación para el diagnóstico de edificios.

Resultados: Tras el análisis de datos se han enumerado 36 diagnósticos de enfermería afirmativas, se presentan con mayor prevalencia, los siguientes: alimentos con problemas de admisión, caquexia, alteración de la eliminación vesical espontánea, higiene deterioro de la cavidad oral, la exposición a la contaminación, el ritmo sostenido, insomnio, abuso de drogas, el alcohol y el tabaco, el aislamiento social, la aceptación y el miedo.

Conclusiones: finales en cuenta que la identificación de perfil de diagnóstico es fundamental para la dirección de las intervenciones de enfermería.

Palabras clave: Procesos de enfermería. Atención de enfermería. Enfermedades transmisibles. 


\section{DINTRODUCTION}

The epidemiological outlook of communicable diseases has changed dramatically in recent years and is currently being observed through the parameter of morbidity and mortality that is presented around the world. However, although the new technological model resulting from the process of globalization offers advances, infectious/communicable diseases pose challenges and demand new forms of care for the affected population, as observed in the pandemic involving the Influenza A (H1N1) virus ${ }^{(1)}$.

In Brazil, the morbidity rate of Infectious and Parasitic Diseases (IPD) dropped in the $20^{\text {th }}$ century due to the massive action of health policies. The mortality rates also dropped. In the 1930s, IPD represented $45.7 \%$ of all the deaths in the country. By 1980, the rate had fallen to $9.3 \%$ and in recent years it dropped to approximately $4.9 \%$, according to the epidemiological bulletin of Sexually Transmitted Diseases ${ }^{(2)}$.

It is therefore a consensus that the status of IPD in Brazil from 1980 to date is complex and requires the greater scientific development of healthcare professionals. Nursing professionals must constantly pursue further education in order to provide an organized and correctly oriented, or systematic, care ${ }^{(1,3)}$.

Consequently, the Systematization of Nursing Care (SNC) is a specific professional activity that presupposes a series of dynamic and interrelated actions, and can be implemented in all the healthcare environments, such as public and private services. The application of SNC for patients with IPD is justified due to the numerous manifestations of disease that affect sufferers, which make this activity complex and enriching ${ }^{(4)}$.

In light of this complexity, Horta believes that systematic actions provide a scale of human needs that are based on the state of balance and imbalance between the parties involved. The activity should therefore be developed according to the scientific method. According to Horta, it is configured as the process of nursing, which is described as the dynamic of systematized and interrelated actions that are organized into the following phases: the history of nursing, care plan, nursing prescription, evolution and prognosis ${ }^{(5)}$.

However, to implement any kind of systematic mechanism for IPD, such as the creation of nursing diagnoses, there must be a common terminology. The documentation of care, according to the nursing process, is only possible with the use of terminology ${ }^{(6)}$. The CIPE is considered the system that unifies nursing language. It emerged as the result of the aspiration of nurses for a system that represents the global nursing practice, enables the projection of tendencies on the needs of patients, the provision of treatment, the use of resources, and the results of nursing care $\mathrm{c}^{(7-8)}$.

Consequently, the CIPE ${ }^{\circ}$ is based on the seven-axes model that contains terms used to construct diagnoses, interventions and results. These axes are focus, judgment, means, action, time, location and client ${ }^{(9)}$.

The search for scientific literature on the CIPE ${ }^{\circ}$ in online databases of the Biblioteca Virtual em Saúde led to the following results: Literatura Latino-Americana e do Caribe (Lilacs) and Literatura Internacional em Ciências da Saúde e Biomédica (Medline); SCOOPUS, CINAHL, revealed the predominance of descriptive and quantitative studies that target the individual-clinical model, studies on the use of $\mathrm{CIPE}^{\circ}$ in the states of Rio Grande do Sul, Santa Catarina, Paraná and Paraíba, and the important contribution of the Associação Brasileira de Enfermagem with the project Classificação Internacional da Prática de Enfermagem na Saúde Coletiva (CIPESC). The database searches also revealed the nonexistence of literature on the use of CIPE in infectious diseases units. Consequently, this study seeks to define the real needs of the subjects at an infectious diseases unit in order to construct systematic, receptive and humanized nursing care for this population.

The knowledge gap on the studied subject led to the question: do nursing practices in the field of infectious diseases support the construction of nursing diagnoses using $\mathrm{CIPE}^{\circ}$ version 2.0?

The aim of this paper is to define the profile of nursing diagnoses for hospitalized patients at an infectious diseases unit.

\section{METHODS}

This is a descriptive study, with a quantitative approach, conducted at the infectious diseases unit of the Alcides Castro teaching hospital, Campina Grande, Paraíba, Brazil. This institution is currently undergoing improvements in view of systematic nursing organizations of the sector. The study population consisted of all the hospitalized and identified subjects at the unit who were receiving care during the study period. It should be noted that the maximum percentage of hospitalizations at the infectious diseases unit does not exceed $10 \%$ of total hospitalizations, and that these patients remain at the unit for three months on average. The subjects for research were selected according to convenience sampling with a consecutive design.

A probability sample without replacement was calculated using the annual average (40) of patients attended at 
the hospital from 2009 to $2013^{(10)}$. The calculation for finite populations with a sampling error of $10 \%$ and a $95 \%$ confidence level ( $Z \infty=1.96)$ was used to build the sample of 19 patients.

The criterion for inclusion were to be hospitalized at the clinic at the time of data collection and to be over 18 years of age. Patients with impaired self awareness and difficulties to communicate were excluded.

Prior to initiating data collection, the study participants were oriented on the specifics of the study and compliance with bioethical principles. Furthermore, the researcher delivered a lecture on the Informed Consent Statement so all participants could clearly understand the purpose of the study and subsequently sign or thumbprint the statement.

Data were collected in January and February 2014 by means of interviews and a physical examination. The instrument listed sociodemographic characteristics such as sex, age group, marital status, occupation, origin, religion and disease. Closed medical reports that were in the patient files were used to categorize the disease. The instrument was not adapted to fit the research scenario because it provided answers to all the queries of the researchers ${ }^{(11)}$.

Thus, the instrument guided the findings of signs and symptoms of the physical examinations and the patient case history, and was constructed according to the Theory of Basic Needs of Wanda Aguiar Horta. These needs were subsequently divided into the sub-categories psycho-biological, psycho-social and spiritual, and contemplated a range of variables, such as categories that assessed the condition of eyes, ears, mouth, heart, lungs, and abdomen $^{(11)}$. To complement the data, oxygen levels were measured using pulse oximetry; blood pressure was measured using a sphygmomanometer and stethoscope; and the heat curve was determined using a thermometer.

Data were collected at the nursing unit of the research subject, observing the privacy of patients, since each nursing unit had only one bed. CMap Tools version 5.03, a software that is freely distributed by the Institute for Human Machine Cognition of the University of West Florida, was used to analyze the findings and illustrate the clinical reasoning of nursing diagnoses. This software was also used to support the authorship of the concept maps created for the study, which were subsequently used to share data with the other users ${ }^{(12)}$. The construction of $\mathrm{CIPE}^{\circ} 2.0$ diagnoses observed the precepts of the International Council of Nurses (ICN). These precepts are the presence of a term of the focal axis and a judgment.

This study was approved by the Comitê de Ética em Pesquisa of the Universidade Federal de Campina Grande ac- cording to CAAE 21420813.2.0000.5182, opinion 510,708, and complied with all the regulatory guidelines and standards of Resolution 466/12 of the Conselho Nacional de Saúde ${ }^{(13)}$.

\section{QRESULTS}

Nineteen subjects between the ages of 46 and 55 (57.89\%) participated in this study. Most of the participants were men (84.22\%), married (63.15\%), farmers (42.10\%), from the municipality of Ingá (63.15\%), in Paraíba, and Catholic (94.74\%). According to the medical diagnosis, most of the patients (84.22\%) had HIV/AIDS.

To construct the diagnostic statements, data were grouped into clinical cases and arranged in a concept map using Cmap Tools. A concept map was created for each patient to better visualize the diagnostic reasoning process. Figure 1 shows the course of the entire diagnoses construction process.

The diagnostic statements totaled 36, of which 25 were considered psycho-biological needs and 11 were considered psycho-social needs, noting that the statements with synonyms totaled 82. However, for a better understanding of the results, the findings of the diagnostic statements were arranged according to the basic human needs, as shown in Table 1.

Table 2 shows the diagnostic statements according to psycho-social needs.

\section{DISCUSSION}

The results showed that the most prevalent statements of the 36 nursing diagnoses were: impaired food intake, cachexia, impaired spontaneous bladder elimination, impaired oral cavity hygiene, exposure to contamination, rapid heart rate, insomnia, drug abuse, alcohol and tobacco abuse, social isolation, acceptance and fear.

It was noted that some of the statements were interconnected, such as impaired oral cavity hygiene that can lead to difficulties in swallowing food, or impaired food intake. CIPE version $2.0^{(14)}$ defines food or nutritional intake as the process of supplying the proteins, minerals, carbohydrates and liposoluble vitamins that are required for growth, normal functions and the maintenance of life. On the other hand, CIPE version 2.0 ${ }^{(14)}$ defines oral hygiene as maintaining oropharyngeal flora.

Many of the research subjects presented impaired flora that was or was not caused by a pathological process, since some of the patients who had been diagnosed with HIV/ AIDS presented impaired mucus that made swallowing difficult and reported odynophagia. The lack of oral hygiene 


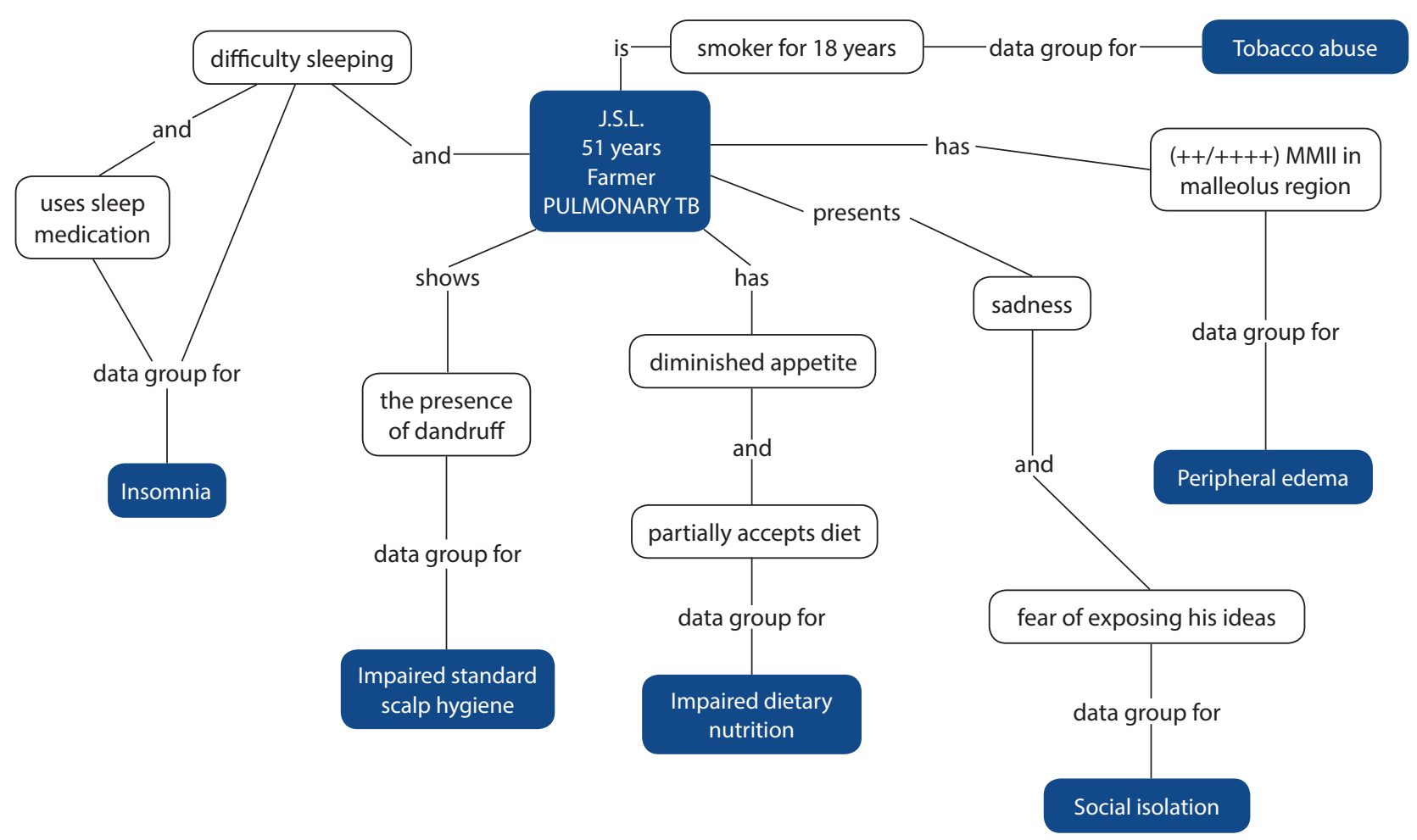

Figure 1 - Schematic diagram of the diagnostic reasoning of the Clinical Case. Campina Grande - PB, 2014

Source: Research information, 2014.

can increase the imbalance of oral mucosa, leading to food abstention, and possibly trigger cachexia that also affects the nutritional support of the subject ${ }^{(15)}$.

The diagnosis cachexia is related to the condition of thinness, muscle loss, lack of strength and weakness usually associated with bad overall health or diseases such as HIV/AIDS and tuberculosis ${ }^{(14)}$. Studies show that people with infectious diseases may or may not present cachexia. In this study, however, the prevalence of cachexia was linked to the fact that most of the participants had been diagnosed with HIV/AIDS. Cachexia was also linked to Systemic Inflammatory Response Syndrome (SIRS) that reduces the production of the hormone ghrelin in the myenteric plexus, which stimulates receptors to promote the feeling of hunger ${ }^{(15-16)}$.

The diagnosis exposure to contamination defined by CIPE version 2.0 as a pathological process ${ }^{(14)}$ was found in the study subjects. This diagnosis is caused by the lack of response of the immune system, and subjects can also become susceptible to contaminants in the hospital environment due to the flora found in the infectious diseases unit, thus providing therapeutic resistance.

Some of the subjects presented urinary impairments that led to voiding dysfunction, i.e. reduced urination, that resulted in oliguria (500 ml/24 hours), and often to anuria (50 ml/24 hours). Many patients had painful urination and reported the presence of urethral exudates ${ }^{(16-17)}$. $\mathrm{CIPE}^{\circ}$ version 2.0 defines impaired spontaneous bladder elimination as any kind of urinary dysfunction that leads to reduces urination ${ }^{(14)}$.

Insomnia, or impaired sleep, was another inference found in the research subjects. In CIPE version 2.0, insomnia is defined as the chronic incapacity to sleep or of remaining asleep throughout the entire night, which is frequently associated to psychological and physical factors ${ }^{(14)}$. The cause of insomnia is presumed to be the result of reactions to medication and to psychological concerns, such as the fear of death and receiving treatment for an infectious disease that is also frowned upon by society ${ }^{(9)}$.

With regard to vascular regulation, the nursing diagnosis rapid heart rate is defined in $\mathrm{CIPE}^{\circ}$ version 2.0 as rate, that is, any type of pathological organ dysfunction that affects cardiac contractility ${ }^{(14)}$. The causes of this irregularity are linked to a range of factors, such as drugs, excess fluid in the cellular spaces and heart diseases. Irregular heart rate is translated as arrhythmias, where the heart rate in adults is above 60-100 bpm, leading to tachycardia, and below 60 bpm, leading to bradycardia(6). 
Table 1 - Distribution of nursing diagnoses of patients with infectious diseases, according to basic psycho-biological human needs at the Hospital Universitário Alcides Carneiro - HUAC, Campina Grande - PB, 2014 ( $n=19)$

\begin{tabular}{lllll}
\multicolumn{1}{c}{$\begin{array}{c}\text { Nursing Diagnoses/ Basic Psycho-biological } \\
\text { Human Needs }\end{array}$} & Yes & $\%$ & No & $\%$ \\
Peripheral edema & 01 & 5.26 & 35 & 94.74 \\
Regurgitation & 01 & 5.26 & 35 & 94.74 \\
Reduced weight & 01 & 5.26 & 35 & 94.74 \\
Impaired defecation & 01 & 5.26 & 35 & 94.74 \\
Excessive bowel elimination & 01 & 5.26 & 35 & 94.74 \\
Drowsiness & 01 & 5.26 & 35 & 94.74 \\
Impaired physical mobility & 01 & 5.26 & 35 & 94.74 \\
Anxiety & 01 & 5.26 & 35 & 94.74 \\
Tremors & 01 & 5.26 & 35 & 94.74 \\
Impaired skin integrity & 01 & 5.26 & 35 & 94.74 \\
Dehydration & 01 & 5.26 & 35 & 94.74 \\
Hyperthermia & 01 & 5.26 & 35 & 94.74 \\
Impaired food intake & 02 & 10.52 & 34 & 89.48 \\
Impaired oral cavity hygiene & 02 & 10.52 & 34 & 89.48 \\
Exposure to contamination & 02 & 10.52 & 34 & 89.48 \\
Rapid heart rate & 02 & 10.52 & 34 & 89.48 \\
Tobacco abuse & 02 & 10.52 & 34 & 89.48 \\
Imbalanced nutrition & 02 & 10.52 & 34 & 89.48 \\
Cachexia & 02 & 15.78 & 33 & 84.22 \\
Impaired spontaneous bladder elimination & 03 & 15.78 & 33 & 84.22 \\
Alcohol and tobacco abuse & 03 & 15.78 & 33 & 84.22 \\
Excess weight & 03 & 21.05 & 32 & 78.95 \\
Impaired scalp hygiene standard & 26.31 & 31 & 73.69 \\
Insomnia & 31.57 & 30 & 68.43 \\
Drug abuse & 03 & 30 & 68.43 \\
\hline
\end{tabular}

Source: Research data, 2014.

The diagnosis of drug, alcohol and tobacco abuse, defined as the excessive or improper use of these substances ${ }^{(14)}$, was prevalent among the research subjects. The excessive use of these substances changes the mood or behavior of users and makes them more vulnerable. Legal drugs like tobacco nicotine alter the viscosity of blood. Alcohol leads to loss of critical judgment, behavior, concentration and awareness. Illegal drugs like cocaine and marijuana lead to symptom exacerbation, such as tachycardia, seizures, ventricular arrhythmias and hallucinations ${ }^{(18)}$.

Finally, psycho-social needs comprised the diagnosis statements of acceptance, fear and social isolation based on the assumptions presented by the study participants. According to CIPE version 2.0, acceptance is defined as managing and controlling feelings of apprehension and tension over time. Fear arises from the feeling of being threatened or disturbed due to known or unknown causes, while social isolation is the incapacity or lack of energy to tolerate or complete activities ${ }^{(14)}$.

Thus, the social conviviality between people with infectious diseases becomes quite restricted when society is aware of their pathological condition. Even when people are unaware of the condition, sufferers tend to resort to social isolation as a defense mechanism, and avoid cer- 
Table 2 - Distribution of nursing diagnoses of patients with infectious diseases, according to basic psycho-social human needs at the Hospital Universitário Alcides Carneiro - HUAC, Campina Grande - PB, 2014 ( $n=19)$

\begin{tabular}{lcccc}
\multicolumn{1}{c}{$\begin{array}{c}\text { Nursing Diagnoses/ Basic Psycho-spiritual } \\
\text { Human Needs }\end{array}$} & Yes & $\%$ & No & $\%$ \\
\hline Ability to communicate due to speech impairment & 01 & 5.26 & 35 & 94.74 \\
Altered state of consciousness & 01 & 5.26 & 35 & 94.74 \\
Family support & 01 & 5.26 & 35 & 94.74 \\
Loneliness & 01 & 5.26 & 35 & 94.74 \\
Acceptance & 02 & 10.52 & 34 & 89.48 \\
Fear & 02 & 10.52 & 34 & 89.48 \\
Social isolation & 05 & 26.31 & 31 & 73.69 \\
\hline
\end{tabular}

Source: Research data, 2014.

tain types of environments that they consider potentially discriminatory ${ }^{(19)}$.

Therefore, many of the patients are isolated and reject help, or they expose their fears and anxiety in relation to their condition and their future because they are still experiencing the stigma of society. It was noted that the study subjects did not feel comfortable talking about their religion, which could be related to fear, and isolated themselves from any form of contact or even of therapeutic practices ${ }^{(20)}$.

\section{CONCLUSIONS}

Data analysis produced a profile of nursing diagnoses of hospitalized patients in an infectious diseases unit. This profile helps to improve nursing practices and to define future interventions and results. The results also show the importance of $\mathrm{CIPE}^{\circ}$ to improve nursing practices.

The nursing diagnoses comprised 36 statements that were divided into psycho-biological and psycho-social needs, with a greater incidence of impaired food intake, cachexia, impaired spontaneous bladder elimination, impaired oral cavity hygiene, exposure to contamination, rapid heart rate, insomnia, drug abuse, alcohol and tobacco abuse, social isolation, acceptance and fear.

This study was restricted to the reality of a municipality in the northeast of Brazil, but it can encourage further research on the use of $\mathrm{CIPE}^{\circ}$ in infectious diseases units.

The results of this study will hopefully help to promote and include this universal language in the description of this professional practice and subsequently improve the quality of nursing care in Brazil.

Further discussion on the forms of nursing care for patients with infectious diseases is required, since it is be- lieved that the scientific evidence provided by this study will lead to improvements in the field of nursing and the associated research, extension and education.

\section{REFERENCES}

1. Yamamura M, Dias AAL, Milani D, Santos EC, Ornelas J, Figueiredo RM. Produção nacional e acesso sobre enfermagem e doenças transmissíveis. UNOPAR Cient, Ciênc Biol Saúde. 2011;13(nesp):299-306.

2. Silva Junior GB, Daher EF. Tropical diseases-associated kidney injury. Rev Bras Clin Med. 2013;11(2):155-64.

3. Oliveira KKD, Fernandes APNL, Moura SGF. Perfil de morbidade por patologias infectocontagiosas entre crianças de 0 a 12 anos. FIEP Bulletin on-line [Internet]. 2012 [cited in 2015 may 10];82(Article II):[7 screens]. Available at: https://fiepbulletin1.websiteseguro.com/index.php/fiepbulletin/article/view/2303/4387

4. Alves AR, Lopes CHAF, Jorge MSB. Significado do processo de enfermagem para enfermeiros de uma unidade de terapia intensiva: uma abordagem interacionista. Rev Esc Enferm USP [Internet]. 2010 [cited in 2014 jan. 09];42(4):649-55. Available at: http://www.scielo.br/pdf/reeusp/v42n4/v42n4a05.pdf.

5. Horta WA. Processo de enfermagem. Rio de Janeiro: Guanabara Koogan; 2011.

6. Araújo AA, Nobrega MML, Garcia TR. Diagnósticos e intervenções de enfermagem para pacientes portadores de insuficiência cardíaca congestiva utilizando a CIPE ${ }^{\circledR}$. Rev Esc Enferm USP. 2013;47(2):385-92.

7. Mattei FD, Toniolo RM, Malucelli A, Cubas MR. Uma visão da produção científica internacional sobre a Classificação Internacional para a Prática de Enfermagem. Rev Gaúcha Enferm. 2011;32(4):823-31.

8. Cubas MR, Carvalho CMG, Malucelli A, Denipote AGM. Mapeamento dos termos dos eixos tempo, localização, meio e cliente entre versões da CIPE ${ }^{\circledR}$ e CIPESC ${ }^{\circledR}$. Rev Bras Enferm. 2011;64(6):1100-5.

9. Siqueira MCF, Bittencourt GKGD, Nóbrega MML, Nogueira JA, Silva AO. Banco de termos para a prática de enfermagem com mulheres idosas com HIV/aids. Rev Gaúcha Enferm. 2015;36(1):28-34.

10. Fontelles MJ, Simões MG, Almeida JC, Fontelles RG. Metodologia da pesquisa: diretrizes para 0 cálculo do tamanho da amostra. Rev Paran Med. 2010;24:(1):57-64. 
11. Andrade LL. Construção de instrumentos para a documentação do processo de enfermagem em uma clínica de doenças infectocontagiosas [dissertação]. João Pessoa: Universidade Federal da Paraíba; 2012.

12. Tavares R. Construindo mapas conceituais. Ciências Cognição. 2007;12(1)72-85.

13. Ministério da Saúde (BR). Conselho Nacional de Saúde. Resolução nº 466, de 12 de dezembro de 2012. Diretrizes e normas regulamentadoras de pesquisas envolvendo seres humanos. Diário Oficial da União [da] República Federativa do Brasil. 2013 jun. 13;150(112 Seção 1):59-62.

14. Cipe versão 2: Classificação Internacional para a Prática de Enfermagem: versão 2.0. São Paulo: Algol Editora; 2011.

15. Nettina SM. Prática de enfermagem. 9. ed. Rio de Janeiro: Guanabara Koogan; 2009.

16. Smeltzer SC, Bare BG. Tratado de enfermagem médico-cirúrgica. 12. ed. Rio de Janeiro: Guanabara Koogan; 2011.
17. Costa AGS, Oliveira ARS, Alves FEC, Chaves DBR, Moreira RP, Araújo TL. Diagnóstico de enfermagem mobilidade física prejudicada em pacientes acometidos por acidente vascular encefálico. Rev Esc Enferm USP. 2010;44(3):753-8

18. Cardoso LRD, Malbergier A, Figueiredo TFB. 0 consumo de álcool como fator de risco para a transmissão das DSTs/HIV/aids. Rev Psiq Clín. 2013;35(1):70-5.

19. Costa TL, Oliveira DC, Formozo GA, Gomes AMT. Pessoas com HIV/aids nas representações sociais de enfermeiros: análise dos elementos centrais, contranormativos e atitudinais. Rev Latino-Am Enfermagem. 2012;20(6):1091-9.

20. Ducan BB, Chor D, Aquino EML, Bensenor IM, Mil JG, Schmidt MI, et al. Doenças crônicas não transmissíveis no Brasil: prioridade para enfrentamento e investigação. Rev Saúde Pública. 2012;46(1):126-34.

\section{Author's address:}

Vinicius Lino de Souza Neto

Universidade Federal do Rio Grande do Norte,

Centro de Ciências da Saúde - Departamento

de Enfermagem

Campus Central, s/n, Lagoa Nova

59078-970 Natal - RN

E-mail: vinolino@hotmail.com
Received: 11.11.2014

Approved: 03.07.2015 